International Journal of Current Advanced Research

ISSN: O: 2319-6475, ISSN: P: 2319 - 6505, Impact Factor: SJIF: 5.995

Available Online at www.journalijcar.org

Volume 6; Issue 3; March 2017; Page No. 2747-2749

DOI: http://dx.doi.org/10.24327/ijcar.2017.2749.0096

Review Article

\title{
A REVIEW ON THE CARDIAC FUNCTION DURING EXERCISE
}

\author{
Pranati .T1 and Gowri Sethu ${ }^{2}$
}

${ }^{1}$ BDS $1^{\text {st }}$ year, Saveetha Dental College \& Hospitals, Chennai -600 077

2Department of physiology, Saveetha Dental College \& Hospitals, Chennai- 600077

\section{A R T I C L E I N F O}

\section{Article History:}

Received $8^{\text {th }}$ December, 2016

Received in revised form $19^{\text {th }}$ January, 2017

Accepted $12^{\text {th }}$ February, 2017

Published online $28^{\text {th }}$ March, 2017

Key words:

Cardiac function, Cardiac function and exercise

\begin{abstract}
A B S T R A C T
Topic: A review on the cardiac function during exercise.

Aim: To do a review on the benefits and mechanism of cardiac function during exercise.

Objective: As there are many positive outcomes on our health due to the alterations in cardiac function during exercise, this topic has gained importance.

Background: Cardiac function is altered during exercise. Cardiac output is the amount of blood that each ventricle pumps per minute. Cardiac output increases during exercise because the heart is trying to meet the muscles need for increased levels of oxygen. This is essential for the muscles to keep going. The maximum cardiac output during exercise is an indication of a healthy heart.
\end{abstract}

Reasons: This study is to create awareness about the good effects of exercise on cardiac function.

Copyright $@ 2017$ Pranati .T and Gowri Sethu. This is an open access article distributed under the Creative Commons Attribution License, which permits unrestricted use, distribution, and reproduction in any medium, provided the original work is properly cited.

\section{INTRODUCTION}

Human heart has the ability to meet the changing demands of circulation i.e. changing preload (venous return) and afterload (arterial impedance) by changing its ability to empty and fill [1]. The cardiac function differs during exercise and at rest[2]. During exercise there is an increased demand for oxygen from the tiring muscles [3] and to meet this demand, the heart beats faster (increased heart rate) and the amount blood pumped per beat (stroke volume) is increased [3,4]. This leads to the increase in cardiac output i.e. the product of heart rate and stroke volume [4]. Exercise, a common physiological stress, can elicit cardiovascular abnormalities that are not present at rest, and it can be used to determine the adequacy of cardiac function [5].

\section{Cardiac function at rest in healthy individuals}

In a healthy individual at rest, the values of various cardiac measures are as follows:

At rest, inspiratory unloading progressively decreased stroke volume index in healthy individuals [11]. Stroke volume index or SVI is the volume of blood pumped by the heart with each beat (in millimetres) divided by the body surface area (square meters). At rest, a typical systolic blood pressure in a healthy individual ranges from $110-140 \mathrm{mmHg}$ and $60-$ 90mmHg for diastolic blood pressure [9]

\section{*Corresponding author: Pranati .T}

BDS $1^{\text {st }}$ year, Saveetha Dental College \& Hospitals, Chennai $-600077$

\begin{tabular}{ccc}
\hline Measure & Right ventricle & Left ventricle \\
\hline End-diastolic volume & $144 \mathrm{~mL}( \pm 23 \mathrm{~mL})[6]$ & $142 \mathrm{~mL}( \pm 21 \mathrm{~mL})[7]$ \\
End systolic volume & $50 \mathrm{~mL}( \pm 14 \mathrm{~mL})[6]$ & $47 \mathrm{~mL}( \pm 10 \mathrm{~mL})[7]$ \\
Stroke volume & $94 \mathrm{~mL}( \pm 15 \mathrm{~mL})[6]$ & $95 \mathrm{~mL}( \pm 14 \mathrm{~mL})[7]$ \\
Ejection fraction & $66 \%( \pm 6 \%)[6]$ & $67 \%( \pm 4.6 \%)[7]$ \\
& $60-100 \mathrm{bpm}[8]$ & $60-100 \mathrm{bpm}[8]$ \\
Heart rate & In athletes $28-40 \mathrm{bpm}[9]$ & In athletes 28-40 bpm[9] \\
Cardiac output & $4.0-8.0 \mathrm{~L} /$ minute[10] & $4.0-8.0 \mathrm{~L} /$ minute[10] \\
\hline
\end{tabular}

\section{Cardiovascular adaptations to exercise}

Cardiac output during exercise increases greatly owing to the relatively high heart rates that are achieved during exercise. Heart rate increases proportionately with workload until heart rates close to maximal are attained. It is remarkable that exercise heart rates six to seven times resting values are not associated with a fall in stroke volume, which is maintained byincreased venous return, and increased myocardial contractibility. Despite the great changes in cardiac output, increases in blood pressure during exercise are maintained within relatively smaller limits, as both pulmonary and systemic vascular resistance to blood flow is reduced. Redistribution of blood flow to the working muscles during exercise also contributes greatly to the efficient delivery of oxygen to sites of greatest need. [12]

\section{Cardiac function during exercise in healthy individuals}

Before exercise even begins heart rate increases in anticipation. This is known as the anticipatory response. It is mediated through the releases of a neurotransmitters called epinephrine and norepinephrine also known as adrenaline and noradrenaline [13]. After the initial anticipatory response, heart rate increases in direct proportion to exercise intensity 
until a maximum heart rate is reached. Maximum heart rate is estimated with the formula 220-age. But this is only an estimation, and not particularly accurate. The only direct method for determining maximum heart rate is to exercise at increasing intensities until a plateau in heart rate is found despite the increasing work rate. [14] Stroke volume can increase as much as $150-220 \mathrm{ml} /$ beat [9]. Stroke volume may increase only up to $40-60 \%$ of maximal capacity after which it plateaus. Beyond this relative exercise intensity, stroke volume remains unchanged right up until the point of exhaustion $[15,16]$. Cardiac output increases proportionally with exercise intensity - which is predictable from understanding the response of heart rate and stroke volume to activity.During intense exercise this can increase to 2040L/min [13]. At rest $15-20 \%$ of circulating blood supplies skeletal muscle. During vigorous exercise this increases to 80$85 \%$ of cardiac output. Blood is shunted away from major organs such as the kidneys, liver, stomach and intestines. It is then redirected to the skin to promote heat loss [9]. During exercise systolic pressure, the pressure during contraction of the heart (known as systole) can increase to over $200 \mathrm{mmHg}$ and levels as high as $250 \mathrm{mmHg}$ have been reported in highly trained, healthy athletes [9]. Diastolic pressure on the other hand remains relatively unchanged regardless of exercise intensity.

\section{Cardiac function at rest and during exercise in patients with ischemic heart disease}

Although coronary angiography defines regions of potential ischemia in patients with Coronary Artery disease, accurate assessment of the presence and functional importance of ischemia requires appraisal of regional and global left ventricular function during stress. In a study done by Jeffrey et $\mathrm{al}$, the results are as follows: in 11 patients with coronary disease who had normal regional and global ventricular function at rest, new regions of dysfunction developed during exercise $(\mathrm{P}<0.001)$, and in 10 , global ejection fraction dropped 7 to 47 per cent [17]. In a study done by K T Weber et al, among 40 patients with heart failure of varying severity, it was found that increase in severity of heart failure progressively decreased exercise capacity (from $1157+/-154$ to $373+/-157$ seconds) and maximum VO2 $(23+/-3.2$ to 8.4 $+/-1.5 \mathrm{ml} / \mathrm{min} / \mathrm{kg}$ ). These decreases corresponded with the reduced maximum cardiac output and stroke volume during exercise. [18]

\section{Clinical assessment of cardiac function:}

\section{Treadmill test}

The cardiac stress test is done with heart stimulation, by exercise on a treadmill with the patient connected to an electrocardiogram (ECG). Cardiac stress tests compare the coronary circulation while the patient is at rest with the same patient's circulation during maximum physical exertion, showing any abnormal blood flow to the myocardium (heart muscle tissue). This test can be used to diagnose coronary artery disease (also known as ischemic heart disease) and assess patient prognosis after a myocardial infarction (heart attack) [19].

\section{Echocardiography}

Echocardiogram is a device which directs ultrasonic waves towards heart. The sound waves are then reflected back when they reach tissues of differing acoustic impedance, thereby forming the basis of the echo principle [20]. Echocardiography uses standard two-dimensional, threedimensional, and Doppler ultrasound to create images of the heart [21]. It can provide a wealth of helpful information, including the size and shape of the heart (internal chamber size quantification), pumping capacity, and the location and extent of any tissue damage [22]. It also helps physicians to calculate cardiac output, ejection fraction and diastolic function [23]. Echocardiography performed immediately after exercise has shown to be useful to assess the prognosis of degenerative MR [24].

\section{Stress echocardiography}

Echocardiography performed after exercise is called stressechocardiography. This is done to compare the structural differences before and after exercise. The patient is subjected to stress in the form of exercise or chemically (usually dobutamine). After the target heart rate is achieved, 'stress' echocardiogram images are obtained. The two echocardiogram images are then compared to assess for any abnormalities in wall motion of the heart [25]. This is used to detect obstructive coronary artery disease [26]. This is usually accompanied by treadmill test (ECG) [25].

\section{CONCLUSION}

Human body has a great ability to change its mechanisms to adjust the body to changing environments and conditions and thus maintain homeostasis. One such frequently changing mechanism is the functioning of heart. The heart functions in different ways in rest and during exercise. This difference helps physicians to find any abnormality associated with heart.

\section{References}

1. Book: "Atlas of HEART FAILURE: Cardiac function and Dysfunction" Arnold M.Katz

2. Book: "Sports Cardiology: Exercise in health and cardiovascular disease" C. De Landsheere and P. Rigo

3. Salmasi, Abdul-Majeed. "Cardiac output during exercise." Cardiac Output and Regional Flow in Health and Disease. Springer Netherlands, 1993. 9196.

4. Christie, Jeffrey, Lois M. Sheldahl, Fellix E. Tristani, Kiran B. Sagar, Michael J. Ptacin, and Samuel Wann. "Determination of stroke volume and cardiac output during exercise: comparison of twodimensional and Doppler echocardiography, Fick oximetry, and thermodilution." Circulation 76, no. 3 (1987): 539-547.

5. Fletcher, Gerald F., Gary J. Balady, Ezra A. Amsterdam, Bernard Chaitman, Robert Eckel, Jerome Fleg, Victor F. Froelicher et al. "Exercise standards for testing and training." Circulation 104, no. 14 (2001): 1694-1740.

6. Maceira, Alicia M., Sanjay K. Prasad, Mohammed Khan, and Dudley J. Pennell. "Reference right ventricular systolic and diastolic function normalized to age, gender and body surface area from steadystate free precession cardiovascular magnetic resonance." European heart journal 27, no. 23 (2006): 2879-2888. 
7. Maceira, A. M., S. K. Prasad, M. Khan, and D. J. Pennell. "Normalized left ventricular systolic and diastolic function by steady state free precession cardiovascular magnetic resonance." Journal of Cardiovascular Magnetic Resonance8, no. 3 (2006): 417-426.

8. Normal ranges for heart rate are among the narrowest limits between bradycardia and tachycardia. Wikipedia

9. Wilmore JH and Costill DL. (2005) Physiology of Sport and Exercise: $3^{\text {rd }}$ Edition. Champaign, IL: Human Kinetics

10. Edwards Lifesciences LLC > Normal Hemodynamic Parameters - Adult 2009

11. Lalande, Sophie, Charles E. Luoma, Andrew D. Miller, and Bruce D. Johnson. "Effect of changes in intrathoracic pressure on cardiac function at rest and during moderate exercise in health and heart failure." Experimental physiology 97, no. 2 (2012): 248-256.

12. Evans, D. L. "Cardiovascular adaptations to exercise and training." The Veterinary clinics of North America. Equine practice 1.3 (1985): 513-531.

13. McArdle WD, Katch FI and Katch VL. (2000) Essentials of Exercise Physiology: $2^{\text {nd }}$ edition Philadelphia, PA: Lippincott Williams \& Wilkins.

14. The cardiovascular system and exercise - sports fitness advisor

15. Crawford MH, Petru MA, Rabinowitz C. Effect of isotonic exercise training on left ventricular volume during upright exercise. Circulation. 1985 Dec;72(6);1237-43

16. Higginbotham MB, Morris KG, Williams RS, McHale PA, Coleman RE, Cobb FR. Regulation of stroke volume during submaximal and maximal upright exercise in normal man. Cric Res. 1986 Feb;58(2):281-91
17. Borer, Jeffrey S., Stephen L. Bacharach, Michael V. Green, Kenneth M. Kent, Stephen E. Epstein, Gerald S. Johnston, and Bonnie Mack. "Real-time radionuclide cineangiography in the noninvasive evaluation of global and regional left ventricular function at rest and during exercise in patients with coronary-artery disease." New England Journal of Medicine 296, no. 15 (1977): 839-844.

18. Weber, Karl T., GARY T. Kinasewitz, JOSEPH S. Janicki, and ALFRED P. Fishman. "Oxygen utilization and ventilation during exercise in patients with chronic cardiac failure." Circulation 65 , no. 6 (1982): 1213-1223.

19. https://www.nlm.nih.gov/medlineplus/ency/article/00 3878.htm

20. Book: "Pioneers of Medicine Without a Nobel Prize." BhavnaBatohi and Paul S. Sidhu.

21. Book: " Chronic Coronary Artery Disease: A Companion to Braunwald's Heart Disease" James de Lemos, TorbjørnOmland

22. Echocardiography-Wikipedia

23. Cheitlin, Melvin D., et al. "ACC/AHA guidelines for the clinical application of echocardiography." Circulation 95.6 (1997): 1686-1744.

24. Lee, R., B. Haluska, D. Y. Leung, C. Case, J. Mundy, and Thomas H. Marwick. "Functional and prognostic implications of left ventricular contractile reserve in patients with asymptomatic severe mitral regurgitation." Heart 91, no. 11 (2005): 1407-1412.

25. https://medlineplus.gov/ency/article/003878.htm

26. Lago, Rodrigo M., and Thomas A. LaMattina. "Chronic coronary artery disease." MGH Cardiology Board Review. Springer London, 2014. 67-85.

\section{Please cite this article in press as:}

Pranati .T and Gowri Sethu (2017), A Review on The Cardiac Function During Exercise, International Journal of Current Advanced Research, 6(3), pp. 2747-2749.

http://dx.doi.org/10.24327/ijcar.2017. 2749.0096 